\title{
Empirical Research on the Effect of Independent Audit Opinion on Trade Credit
}

\author{
Han Dongping ${ }^{1, a}$, Yu Huaiyu ${ }^{2, b *}$ \\ ${ }^{1}$ School of Economics and Management Harbin Institute of Technology Weihai, China \\ ${ }^{2}$ School of Economics and Management Harbin Institute of Technology Weihai, China
}

\begin{abstract}
This paper takes listed companies from 2014 to 2018 as a research sample. The results show that the independent audit opinion will affect the trade credit decision of the supplier to the enterprise. A good institutional environment can weaken the impact of non-standard independent audit opinion on the cost and scale of trade credit. And good industry environment can weaken the positive correlation between non-standard independent audit opinion and trade credit cost.
\end{abstract}

\section{INTRODUCTION}

Enterprises need to reserve working capital to maintain their daily production and operation. They often need to resort to external financing when they are lack of capital [1]. In China, due to the immature development of bond and stock market, complicated procedures and high issuance cost, short-term financing is not applicable. Therefore, bank loans and trade credit play a role in short-term working capital financing. Compared with banks, trade credit has stronger control over customers, and can recover property losses with its own strong sales network [2]. The use of trade credit can weaken transaction costs, realize the regular settlement of funds between suppliers and sellers, and reduce the use of preventive funds [3]. When transactions are carried out between enterprises, there is often a time difference between payment settlement and delivery of goods, which forms trade credit. Companies often have an in-depth understanding of the financial and operating conditions of the trading company before making trade credit decisions.

Audit is an important means of external supervision. Independent audit opinions are issued by independent third parties and have the function of signal transmission. The type of independent audit opinion will affect the credit decision of suppliers, and in turn affect the scale and mode of trade credit available to enterprises. Existing research proposes the concentration of suppliers [4], the nature of property rights [5], market position [6], industry environment [7] and the level of protection of producers' legitimate rights and interests [5] will affect the effectiveness of independent audit opinions on trade credit.

This article takes the institutional environment and industry environment as moderating variables into the research, explores the impact of independent audit opinion on trade credit, and analyze the influence of institutional environment and industry environment on trade credit.

\section{THEORETICAL ANALYSIS AND ASSUMPTIONS}

\subsection{The Impact of Independent Audit Opinion on Trade Credit}

Suppliers provide trade credit to enterprises and will bear credit risk. Therefore, it is necessary to select a trade credit policy to each transaction party, independent audit opinion can increase the trust of stakeholders in the financial statements. According to the signal transmission theory, the type of independent audit opinion convey different signal can leading to different decisions on trade credit to enterprise suppliers. When a company is issued a standard unqualified independent audit opinion, the supplier will have more confidence in the company's repayment ability, in order to maintain long-term cooperation, and are willing to provide more trade credit, the cost of trade credit will be reduced. On the contrary, suppliers will have doubts about the enterprise, the scale of trade credit that the enterprise can obtain becomes smaller, and the cost of trade credit becomes higher.

H1a: When a company is issued a non-standard independent audit opinion, the cost of trade credit will increase significantly.

H1b: When a company is issued a non-standard independent audit opinion, the scale of trade credit will decrease significantly. 


\subsection{The Regulatory Effect of Institutional Environment}

The institutional environment is closely related to social trust. The better the institutional environment, the more developed market transactions and the more complete the social security mechanism, which will help increase social trust. Independent audit opinion can be used as a trust mechanism to establish a relationship with trade credit. In the case where other trust mechanisms are weak, independent audit opinions play a stronger role [5]. When the trust mechanism of the institutional environment can play a better role, the negative impact of non-standard independent audit opinion on trade credit is reduced. In the case of a good institutional environment, the suppliers' own rights and interests can be effectively protected by law, and in order to expand the sales scale, they will provide trade credit for the enterprise. Conversely, the company's suppliers will worry that due to the lack of legal protection, the scale of trade credit provided will decrease and the cost of trade credit will increase.

H2a: A good institutional environment can weaken the positive correlation between non-standard independent audit opinion and trade credit costs.

H2b: A good institutional environment can weaken the negative correlation between non-standard independent audit opinion and trade credit scale.

\subsection{The Regulatory Effect of Industry Environment}

Companies that are provided with trade credit can realize interest-free short-term financing and obtain additional benefits. For companies with poor industry environment, the negative impact of non-standard independent audit opinion on trade credit cost is more significant than that of companies with good industry environment, but the negative impact of non-standard independent audit opinion on the scale of trade credit does not significant than that companies with good industry environment. The main reasons are as follows, first of all, in terms of trade credit cost, because companies with poor industry environment are difficult to gain the trust of suppliers, there are limited the suppliers can be chosen is limited, and replacement costs are high. Non-standard independent audit opinion have a greater effect on the increase in trade credit costs. Even if a company with a good industry environment is issued a non-standard independent audit opinion, it still has strong bargaining power, and its trade credit costs increase is not as significant as that of a company in a poor industry environment. Then, in terms of the scale of trade credit, according to the theory of credit rationing, the main method of short-term financing for large-scale enterprises is bank loans, while small enterprises are trade credit. When a company is issued a non-standard independent audit opinion and it is difficult to obtain bank credit, small companies will work harder to maintain trade credit relationships with suppliers. As for the scale of trade credit, the issuance of non-standard independent audit opinion may not be more significant to small enterprises.

H3a: Higher industry environment can weaken the positive correlation between non-standard independent audit opinion and trade credit costs.

H3b: Higher industry environment cannot weaken the negative correlation between non-standard independent audit opinion and trade credit scale.

\section{RESEARCH DESIGN}

\subsection{Variable Selection and Data Source}

Selected Shanghai-Shenzhen A-share companies of listed companies from 2014 to 2018 as a sample, this article deals with the raw data as follows: 1. Excluding the financial and insurance industry, because this industry is very different from other non-financial industries in terms of financial status, business model, etc.; 2. Eliminate missing values. The final retained sample size is 12460 .

The financial data and independent audit opinion in this article are from the the CSMAR database. The institutional environmental indicators refer to the marketization process comprehensive index data from "China's Provincial Marketization Index Report 2018 Edition". Use EVIEWS and SPSS for regression analysis, correlation analysis, and descriptive statistical analysis.

TABLE I. VARIABLE DEFINITION TABLE

\begin{tabular}{|l|l|l|l|}
\hline \multicolumn{1}{|c|}{ Type } & \multicolumn{1}{c|}{ Variable } & \multicolumn{1}{c|}{ Symbol } & \multicolumn{1}{c|}{ Definition } \\
\hline \multirow{2}{*}{$\begin{array}{l}\text { Dependent } \\
\text { Variable }\end{array}$} & trade credit cost & cost & $\begin{array}{l}\text { (Prepaid Account- Payable account) } / \\
\text { Total liabilities }\end{array}$ \\
\cline { 2 - 4 } & trade credit scale & credit & $\begin{array}{l}\text { [Payable account(t)- Payable } \\
\text { account(t-1)]/ Total assets }\end{array}$ \\
\hline $\begin{array}{l}\text { Independent } \\
\text { Variable }\end{array}$ & $\begin{array}{l}\text { independent audit } \\
\text { opinion }\end{array}$ & opin & $\begin{array}{l}\text { If received a non-standard audit opinion } \\
\text { take 1, otherwise take 0 }\end{array}$ \\
\hline \multirow{2}{*}{$\begin{array}{l}\text { Moderator } \\
\text { variable }\end{array}$} & $\begin{array}{l}\text { Institutional } \\
\text { environment }\end{array}$ & dma & $\begin{array}{l}\text { Overall score of the marketi- zation index } \\
\text { of the city }\end{array}$ \\
\cline { 2 - 4 } & $\begin{array}{l}\text { industry } \\
\text { environment }\end{array}$ & indu & $\begin{array}{l}\text { If the ratio is higher than the median, take } \\
\text { 1, otherwise take 0 }\end{array}$ \\
\hline \multirow{2}{*}{$\begin{array}{l}\text { Control } \\
\text { Variable }\end{array}$} & Profitability & roe & Return on equity \\
\cline { 2 - 4 } & Asset-liability & lev & Total liabilities/ Total assets \\
\cline { 2 - 4 } & $\begin{array}{l}\text { Ownership } \\
\text { concentration }\end{array}$ & top1 & $\begin{array}{l}\text { Shareholding ratio of the largest } \\
\text { shareholder }\end{array}$ \\
\cline { 2 - 4 } & \multicolumn{2}{|c}{} \\
\cline { 2 - 4 }
\end{tabular}




\begin{tabular}{|l|l|l|l|}
\hline Growth ability & growth & Operating income growth rate \\
\hline Bank loan & bank & $\begin{array}{l}\text { (Short Term Loan+ Non- current } \\
\text { liabilities)/ Total assets }\end{array}$ \\
\cline { 2 - 4 } & Year & year & Year dummy variable \\
\hline Position & market & Position dummy variable \\
\hline
\end{tabular}

\subsection{Model Construction}

This article refers to the research of Zhang Yong to construct a multiple regression model. Models 1 and 2 are used to explore the impact of audit opinion on trade credit costs and scale, and $\mathrm{H} 1$ is verified. Afterwards, the institutional environment variable were examine the relationship between audit opinion and trade credit costs and scale. Models 3 and 4 were established to verify H2. Finally, industry environment indicators were introduced, and the crossover items of industry environment and audit opinion were examine the relationship between industry environment, independent audit opinion and trade credit costs and scale, and establish models 5 and 6 to verify $\mathrm{H} 3$.

Cost $=a_{0}+a_{1}$ OPIN $+a_{2}$ BANK $+a_{3}$ LEV $+a_{4}$ ROE + $a_{5}$ GROWTH $+a_{6}$ SHR $1+\sum$ year $+\sum$ market $+\varepsilon$

Credit $=a_{0}+a_{1}$ OPIN $+a_{2}$ BANK $+a_{3}$ LEV $+a_{4}$ ROE + $a_{5}$ GROWTH $+a_{6}$ SHR $1+\sum$ year $+\sum$ market $+\varepsilon$

Cost $=a_{0}+a_{1}$ OPIN $+a_{2}$ DMA $+a_{3}$ OPIN $*$ DMA $+a_{4}$ BANK $+a_{5} \mathrm{LEV}+a_{6}$ ROE $+a_{7} \mathrm{GROWTH}+a_{8} \mathrm{SHR} 1+\sum$ year +

$\sum$ market $+\varepsilon$

Credit $=a_{0}+a_{1}$ OPIN $+a_{2}$ DMA $+a_{3}$ OPIN $*$ DMA $+a_{4} \mathrm{BANK}+a_{5} \mathrm{LEV}+a_{6}$ ROE $+a_{7} \mathrm{GROWTH}+a_{8} \mathrm{SHR} 1+$ $\sum$ year $+\sum$ market $+\varepsilon$

Cost $=a_{0}+a_{1}$ OPIN $+a_{2}$ INDU $+a_{3}$ OPIN $*$ POSITION + $a_{4} \mathrm{BANK}+a_{5} \mathrm{LEV}+a_{6} \mathrm{ROE}+a_{7} \mathrm{GROWTH}+a_{8} \mathrm{SHR} 1+$ $\sum$ year $+\sum$ market $+\varepsilon$

Credit $=a_{0}+a_{1}$ OPIN $+a_{2}$ INDU $+a_{3}$ OPIN $*$ INDU $+a_{4} \mathrm{BANK}+a_{5} \mathrm{LEV}+a_{6} \mathrm{ROE}+a_{7} \mathrm{GROWTH}+a_{8} \mathrm{SHR} 1+$

$\sum$ year $+\sum$ market $+\varepsilon$

\section{EMPIRICAL ANALYSIS}

\subsection{Descriptive Statistics}

As shown in Table II, the explanatory variable CREDIT indicates that most companies have issued standard unqualified independent audit opinion. The explanatory variable COST indicates that the advance payment of most companies is less than the amount payable, and it is usually used as the provider of trade credit in the procurement process. For the explanatory variable INDU, the incomplete average division is caused by the removal of missing values and the calculation error of the median. The explanatory variable DMA indicates that the sample companies are mainly distributed in a better system environment.

TABLE II. DESCRIPTIVE STATISTICS FOR MAJOR VARIABLE

\begin{tabular}{|c|c|c|c|c|c|}
\hline $\begin{array}{c}\text { Variabl } \\
\mathbf{e}\end{array}$ & $\begin{array}{c}\text { Minimu } \\
\mathbf{m}\end{array}$ & $\begin{array}{c}\text { Maximu } \\
\mathbf{m}\end{array}$ & Mean & $\begin{array}{c}\text { Standar } \\
\mathbf{d} \\
\text { Deviatio } \\
\mathbf{n}\end{array}$ & $\begin{array}{c}\text { Media } \\
\mathbf{n}\end{array}$ \\
\hline credit & -6.793 & 0.625 & $\begin{array}{c}-0.00 \\
7\end{array}$ & 0.111 & 0.002 \\
\hline cost & -0.920 & 2.328 & -0.13 & 0.198 & -0.113 \\
\hline opin & 0.000 & 1.000 & 0.034 & 0.182 & 0.000 \\
\hline bank & 0.000 & 0.849 & 0.115 & 0.130 & 0.086 \\
\hline lev & 0.014 & 1.758 & 0.442 & 0.637 & 0.419 \\
\hline roe & -29.144 & 8.715 & 0.045 & 0.489 & 0.067 \\
\hline growth & -0.988 & 429.036 & 0.394 & 5.167 & 0.109 \\
\hline top1 & 2.197 & 89.990 & 34.28 & 14.683 & 32.160 \\
\hline indu & 0.000 & 1.000 & 0.614 & 0.503 & 1.000 \\
\hline dma & 0.070 & 10.830 & 8.458 & 1.800 & 9.290 \\
\hline
\end{tabular}

\subsection{Regression Analysis}

TABLE III. VARIABLE REGRESSION COEFFICIENTS

\begin{tabular}{|c|c|c|c|c|c|c|c|c|c|c|}
\hline \multirow{3}{*}{ Variable } & $\begin{array}{c}\text { Model } \\
1 \\
\end{array}$ & Model 2 & Model 3 & Model 4 & Model 5 & $\begin{array}{c}\text { Model } \\
5 \\
\end{array}$ & Model 5' & Model 6 & $\begin{array}{c}\text { Mode } \\
\text { 6' } \\
\end{array}$ & $\begin{array}{c}\text { Model } \\
\text { 6' }\end{array}$ \\
\hline & & & & & & indu $=1$ & indu $=0$ & & indu $=1$ & indu $=0$ \\
\hline & COST & SIZE & COST & SIZE & COST & COST & SIZE & SIZE & COST & SIZE \\
\hline Constant & -0.109 & 0.013 & -0.037 & 0.000 & -0.106 & -0.161 & -0.080 & 0.007 & 0.008 & 0.022 \\
\hline OPIN & 0.045 & -0.047 & 0.136 & -0.118 & 0.049 & 0.001 & 0.062 & -0.033 & -0.076 & -0.034 \\
\hline BANK & 0.312 & 0.015 & 0.313 & 0.016 & 0.300 & 0.534 & 0.183 & 0.013 & 0.017 & 0.005 \\
\hline LEV & -0.007 & -0.003 & -0.007 & -0.003 & -0.008 & -0.120 & -0.002 & -0.004 & 0.007 & -0.002 \\
\hline ROE & 0.006 & 0.007 & 0.007 & 0.005 & 0.008 & 0.015 & 0.007 & 0.006 & 0.016 & 0.004 \\
\hline GROWTH & 0.000 & 0.001 & 0.000 & 0.001 & 0.000 & 0.000 & 0.001 & 0.001 & 0.001 & 0.002 \\
\hline TOP1 & -0.001 & 0.000 & -0.001 & 0.000 & -0.001 & -0.001 & -0.001 & 0.000 & 0.000 & 0.000 \\
\hline DMA & & & -0.008 & -0.128 & & & & & & \\
\hline
\end{tabular}




\begin{tabular}{|c|c|c|c|c|c|c|c|c|c|c|}
\hline DMA*OPIN & & & -0.013 & 0.001 & & & & & & \\
\hline INDUSTRY & & & & & -0.025 & & & 0.004 & & \\
\hline $\begin{array}{l}\text { INDUSTRY*OPI } \\
\mathrm{N}\end{array}$ & & & & & -0.045 & & & -0.041 & & \\
\hline YEAR & Control & Control & Control & Control & Control & Control & Control & Control & Control & Control \\
\hline MARKET & Control & Control & Control & Control & Control & Control & Control & Control & Control & Control \\
\hline $\mathrm{R}^{2}$ & 0.2321 & 0.0865 & 0.2270 & 0.0880 & 0.2231 & 0.2686 & 0.2168 & 0.0876 & 0.1012 & 0.0803 \\
\hline Adjusted R & 0.2196 & 0.0845 & 0.2252 & 0.0859 & 0.2213 & 0.2655 & 0.2133 & 0.0855 & 0.0974 & 0.0763 \\
\hline F-statistic & 129.840 & 43.673 & 134.690 & 42.367 & 123.095 & 86.459 & 63.807 & 41.195 & 28.071 & 19.850 \\
\hline Prob(F-statistic) & 0.0000 & 0.0000 & 0.0000 & 0.0000 & 0.0000 & 0.0000 & 0.0000 & 0.0000 & 0.0000 & 0.0000 \\
\hline Observations & 12460 & 12460 & 12460 & 12460 & 12460 & 6489 & 6002 & 12460 & 6489 & 6002 \\
\hline
\end{tabular}

The regression results of models 1 and 2 show that the non-standard audit opinion of the previous year is significantly positively correlated with the cost of trade credit, indicating that when non-standard audit opinion are issued, the company's trade credit costs will increase, which verified H1a. The non-standard independent audit opinion of the previous year was significantly negatively correlated with the scale of trade credit, indicating that when a company was issued a non-standard independent audit opinion, it would cause stakeholders to have concerns about the company's operating results, financial status, etc. As a result, the supply of trade credit funds to the enterprise was weaken, and the company's trade credit scale was significantly reduced, H1b was verified.

The regression results of models 3 and 4 show that independent audit opinion is significantly positively correlated with trade credit costs, which further validates H1a. Institutional environment indicators are significantly negatively correlated with trade credit costs, indicating that the better institutional environment, the lower trade credit costs. Institutional environment indicators and independent audit opinions are negatively correlated with trade credit costs, that means a good institutional environment can alleviate the increase in trade credit costs caused by non-standard independent audit opinion, verifying $\mathrm{H} 2 \mathrm{a}$. The independent audit opinion is significantly negatively correlated with the scale of trade credit, which further validates $\mathrm{H} 1 \mathrm{~b}$. There is a significant positive correlation between the institutional environment and the scale of trade credit, and the cross-products of the institutional environment indicators and independent audit opinions are positively correlated with the scale of trade credit. It shows that the better the institutional environment in the region where the enterprise is located, the higher the scale of trade credit that the enterprise can obtain, and when the enterprise is in a good institutional environment, the negative impact of non-standard independent audit opinion on the scale of trade credit will be alleviated, which verified $\mathrm{H} 2 \mathrm{~b}$.

The regression results of model 5 show that non-standard independent audit opinions are positively correlated with trade credit costs, industry environment is negatively correlated with trade credit costs, and the crossover between industry environment and audit opinion is negatively correlated with trade credit costs. It shows that the better industry environment a company is in, the easier it is to obtain trade credit facilities at a lower cost. Moreover, the negative impact of non-standard independent audit opinions on trade credit costs has also been eased. In order to further verify this hypothesis, we adopt a group regression method to test, such as model 5'. In the better industry environment group, the audit opinion is not related to the trade credit costs. In the poor industry environment group, the audit opinion significantly positive correlation with trade credit costs, indicating that if the company is in a better industry environment, the issuance of non-standard audit opinion will not have a significant impact on the company's trade credit costs, and if the company's industry environment is poor, it will produces a series of bad influences. The above conclusion verify $\mathrm{H} 3 \mathrm{a}$.

The regression results of model 6 show that independent audit opinion are negatively correlated with the scale of trade credit, industry environment is positively correlated with the scale of trade credit, and the crossover between industry environment and independent audit opinion is negatively correlated with the scale of trade credit. It shows that the better industry environment of an enterprise, the higher scale of financing through trade credit, but the impact of non-standard independent audit opinion on the reduction of trade credit scale will increase. In order to further verify, we adopt the group regression method to test, model 6 ' shows that when the company is in a better industry environment, the issuance of non-standard independent audit opinion will still significantly weaken the scale of trade credit financing. A good industry environment cannot weaken the effect of non-standard independent audit opinions on the scale of trade credit, verifying the $\mathrm{H} 3 \mathrm{~b}$.

\subsection{Robustness tests}

In order to ensure the reliability of the research results, this paper replaces the explanatory variable indicators to verify the robustness of the original regression results. For the trade credit costs indicator, in the robustness test, the measurement method of Chen Yunsen [7], Liu Fengwei, etc. [8] is used, and the proportion of prepaid account in the sum of payable account, notes payable and prepaid account is used as the trade credit costs substitution variable. And the result is consistent with the original conclusion.

\section{CONCLUSION}

This paper draws the following conclusions through 
empirical analysis: (1) independent audit opinion will affect the enterprise credit decisions of suppliers. Specifically, non-standard independent audit opinions are positively correlated with trade credit costs, and negatively correlated with trade credit scale; (2) a good institutional environment can weaken the negative impact of non-standard independent audit opinion on commercial credit. If the enterprise is located in a poor institutional environment, the positive correlation between non-standard independent audit opinion and the cost of trade credit is more significant, and the negative correlation between non-standard independent audit opinion and the scale of trade credit is more significant; (3) a good industry environment cannot completely weaken the negative impact of non-standard independent audit opinion on trade credit. The specific manifestation is that good industry environment can weaken the negative impact of non-standard independent audit opinion on trade credit costs, but it cannot weaken the negative impact of non-standard independent audit opinion on trade credit. Compared with companies in poor industry environment, the negative correlation between non-standard independent audit opinion and trade credit scale of companies in good industry environment is more significant.

\section{ACKNOWLEDGMENT}

We acknowledge the support from National Natural Science Foundation of China (71672046).

\section{REFERENCES}

1. Karjalainen, J, Audit Quality and Cost of Debt Capital for Private Firms: Evidence from Finland, International Journal of Auditing, 2011.15(1):88-108

2. Petersen, M.A.,Rajan.R.G. Trade Credit:Theories and Evidence[J]. The Review of Financial Studies, 1997.10(3):661-69.

3. Ferris.J.S, A Transactions Theory of Trade Credit Use[J]. The Quarterly Journal of Economics, 1981.96(2):243-270.

4. Zhu Wenli and Bai Junya, Supplier concentration, non-standard independent audit opinions and trade credit financing[J]. Business Research, 2018.(6): 61-70.

5. Zhang Yong, Trust, independent audit opinion and the Trade Credit Financing [J]. Auditing Research, 2013(5): 72-79.

6. Zhang Linyi, The Influence of independent audit opinion on Information Users' Economic Decisions[D]. Jiangxi University of Finance\& Economics, 2015.

7. Chen Yunsen and Wang Yutao, Audit Quality, Transaction Cost and Mode of Trade Credit[J]. Auditing Research, 2010 (6 ):77-85.

8. Liu Fengwei, Li Lin.Trust, Transaction Cost and trade credit model[J]. Economic Research Journal, 2009.(8):60-72. 